\title{
Cooperation Between Parents and School on Sex Education to Prevent Sexual Abuse in Early Childhood Case Study: Sex Education Implementation in Budi Mulia Dua Sedayu Kindergarten
}

\author{
Endah Windiastuti ${ }^{1, *}$ Amir Syamsudin ${ }^{1}$
}

\author{
${ }^{1}$ Early Childhood Education Department, Yogyakarta State University, Yogyakarta, Indonesia \\ *Corresponding author. Email: endahwindiastuti.2018@student.uny.ac.id
}

\begin{abstract}
The awareness of sex education in Indonesia is still low. This concern can be seen by the increase in sexual abuse cases that occurred in the last 3 years. 70 cases in 2017, 149 cases in 2018, and until July of 2019 there were 78 cases of sexual abuse in children. The causes were the lack of control from adults, and sex education is still considered a taboo subject. This paper would like to analyze parents' perspectives about sex education and the school's efforts to implement sex education in Budi Mulia Dua Sedayu Kindergarten. This research uses the qualitative approach with an in-depth interview in examining data with the parents and teachers, observation, also the literature review. The result of this study reveals the following: firstly, parents think that sex education is an important thing as a preventive action to sexual abuse. Secondly, the school has done the program with the explanation and active act in school. However, in reality, some problems occurred like toilets that is not divided by gender, and adult that changes the child's clothes on the open space. The implication of this study is to bring school and parents to know and develop more about their awareness about sex education.
\end{abstract}

Keywords: Sex education, sexual abuse, parents' perspective, parents and school cooperation,

implementation.

\section{INTRODUCTION}

Sex education in Indonesia is still not fully implemented. Contrary to what people may think, sex education only tells about the name of the intimate organs of humans. It can be because sex education is still considered a taboo subject to be discussed in the public. This education has no place at home and even school because adult is not aware of its importance (Marcovitz, 2013). However, sex education is something that must be taught as an effort to prevent sexual abuse that occurs especially in children. The majority of sex offenders against children are the closest people to children. This shows that sexual abuse can happen to anyone and at any time. Cases that occurred in Indonesia reaches up to as many as $80.23 \%$, where the perpetrators of sexual abuse are the closest people to children and as much as $19.77 \%$ of perpetrators are unknown people (Matius, 2019). Victims of sexual abuse are often blamed for various reasons. Though one of the cases can be caused by the lack of knowledge about the reproductive system and gender issues in the general public.

The causes of this taboo represent the adult's childhood life. They felt that sex education materials are about contraception or abortionit need a lot of energies to concentrate. For the teacher, sex education means outsider who comes and teaches the children about these subjects, so they talk about this warily or avoided the subjects entirely (Kendall, 2013). On the other hand, children need to know their gender as their identity. They want to know and learn about it but they are too afraid to ask about it in the classroom. This can make the children afraid to talk about their sexual experiences. This is the cause of sexual abuse in children that even adults would not know that it could happen to their child.

Another cause is the media's effect, children can learn something that maybe can be a dangerous effect on them. Children can access the media freely and can get the information as much as they can, without their ability to filter the bad and good contents. Media with sensitive and sexual content can make children engage in sexual activity earlier in life (Marcovitz, 2013). Based on that issues, adults should teach sex education as early as possible to prevent sexual abuse of children.

Some cases sexual abuse shows that the perpetrators are the victims' close friends. The bad effect of the media without an adult's control, is that the child will search for everything without knowing if the content is good or bad. What they watch will affect their action. They will feel curious about what they watch and they will try it. Once they do it, they will do it again. 
About 246 million children are subject to some form of Gender Based Violence (GBV), including mistreatment, bullying, psychological abuse and sexual harassment in the school or on the way to school. $25 \%$ of children had physical violence and $36 \%$ of children had emotional violence (United Nations Entity for Gender Equality and the Empowerment of Women [UN Woman], 2016).

The effect of sexual abuse can be seen in both the short term and the long term. The psychological effect of the sexual abuse in children can happen in the long term and even short term harm such as it can cause mental stress to the children that can lead to personality disorder like depression, PTSD, suicidal tendencies, and many other personality disorders. The harmful effect can also destroy their physics (Carson, Foster, \& Tripathi, 2013). That is why sex education is something that is needed to be taught in school.

To prevent this case, adults' roles are needed. Adult control of children's activities must be active. The first thing that adults should know is that sex education is not a taboo subject. Sex education should be taught to children. Parents should be taught sex education at home and the school also should taught sex education program at school. In addition, schools and parents can conduct sex education together for better child growth and development.This paper would discover and analyze the sex education program in Budi Mulia Dua Sedayu Kindergarten.

\section{RESEARCH METHOD}

This research uses a qualitative approach. This research was conducted at Budi Mulia Dua Sedayu Kindergarten. This school has sex education in its program. One of the programs is a conference on sex education for children that is held within the data collection time. The research held for one week with the data collection techniques in this study is using non-participatory observation, interview, and documentation. The participants of this research are teachers and parents. Some parents and teachers give their opinion about the research topic and the researcher does not give away their identity. The data is then analysed using interactive analysis from Miles, Huberman, and Saldana (2014) with 3 steps: a) Data condensation, b) Data display, c) Drawing and verifying conclusions.

\section{RESULT AND DISCUSSION}

As a response to the increasing case of sexual abuse in children, parents at Budi Mulia Dua Sedayu Kindergarten agree with the idea that sex education is something that must be applied at home and school. This is because they think that sex education is an effort for children to get to know themselves and as an effort to prevent sexual abuse that can occur to children. Talking about sex is not a shameful thing to do because this is a matter that must be conveyed to the children.

Sex education is a contentious issue. It can create a debate between school, parents, organization, and religious groups
(Gracia, 2015). Therefore, the school must arranged the sex education material into something that can be understood easily so there can be no misinterpretation Mulia Dua Sedayu conducts sex education as sexual health education for children. The material consists of two main points: how to keep personal hygiene; for the vital organs and how to keep yourself safe from the threats, especially from sex abuse threats.

One of the parents said that they always taught their children to be aware of strangers. Their child should be with the teacher, if they are at school, or with the parents if they are at home. They always have a chat together after school or before bed so they can know what their child did at school. This conversation can make a great bonding between the parent and children so their child can speak out their opinion without doubt.

Another parent said, they already teach sex education to their child since the child is at two years old. The parent tells the child the name of their sex organ and says that not everyone can touch it. their bodies are theirs, so no one can touch it without their permission (Sickkid staff, 2019). The parent always ask their child if they don't feel comfortable when the parents touch them. The parent said with this treatment, it will make the children to always feel free to say their opinion. The child will tell what makes them comfortable and what does not. A good attachment between parent and child is bound by the behavior of ongoing support from parents, love, and attention (Keyzers, Weiler, Haddock, \& Dotty, 2019).

On the other hand, the school gave their opinion about sex education. The teacher said that school has its function as a social control to prevent the negative effect of the lack of information about sex education. In the parents meeting, the school did their role to explain their sex education program in school. The school also asks parents to collaborate on sex education (Alldred \& David, 2007).

Some teachers said that sex education contains some explanation about the body, sexual organs, the function, and why we must take care of it. In the classroom, the teacher teaches about sex with some story. The story itself is a story that the teacher makes. The story is told by the teachers in the morning in the circle class. Firstly, the teachers told the story about the organ of the body and then asked the children to answer the questions or to retell the story. The teachers are open to the questions that the children want to know. They will answer it with a friendly answer so the child will know about what they are curious about. To make the child open with the teachers, the teachers provide a good atmosphere of the learning and create a friendly relationship. This action can make a good bond between the teacher and children.

Other teachers explained how sex education should be taught in school. The teacher said that sex education can also be a platform to teach children how to prevent violence that can lead to sexual abuse. The teachers explain about violence or bullying, then they said that violence and bullying are not a good thing to do and that it is wrong. If the children saw the violence or the violence happened to them, the teachers will demonstrate the safe action needed 
to be taken (United Nations Educational, Scientific and Cultural Organization [UNESCO], 2018).

Budi Mulia Dua Sedayu Kindergarten implements sex education in its learning process. The implementation of sex education in Budi Mulia Dua Sedayu Kindergarten was carried out by the teacher and with the help of several professionals. In implementing sex education in Budi Mulia Dua Sedayu Kindergarten, teachers explain and guide the lesson and are assisted by professionals in matters of reproductive health. This is done so that the explanation and guidance given by the teacher can proceed as it should (Sauntson \& Sundaram, 2016). The professional guiding the teacher have to know about the sex education content that will be given to the children, so that the material of the sex education are safe to learn (Marcovitz, 2013).

The first step in sex education is to introduce the name of a child's sex organ. Intimate organ recognition is done with the teacher showing pictures of male and female limbs and notifying the child's sex organs. The teacher explains the intimate organs of children with their real names. The explanation is done by the teacher because the teacher can adjust the language so that children can understand it more easily (Reiss, 2016).

Secondly, children are taught on how to treat their sex organs, such as to always take a shower, cleaning the sex organs with clean water after going to the toilet, and diligently changing their underwear. This teaching is carried out with class discussions and the teacher applies it during toilet training. In the toilet, the teacher guides the children to do the routine. However, the toilet in this school is still not divided by gender and still mixed between gender.

In the next stage, children are taught to look after themselves by teaching about sensitive areas of the child that are performed by singing. This song contains poems that explain the location on the body of children who may and may not be touched. Body locations that should not be touched include the chest, back area, and legs. Children are also given explanations and simulations about things to do when someone touches the sensitive parts of a child. Children are taught to refuse by avoiding, running, or screaming. Not only with adults, but also when they are with friends children are also taught to be careful. One way to be careful is not to let people touch the children's sensitive areas and to fight when their sensitive areas are touched.

Children are told that they are prohibited to touch other people's bodies without their permission. Therefore, children are told not only that their body can't be touch by anyone but also they are told that they cannot touch other people's bodies. This explanation can bring the children to appreciate others. Furthermore, the children will know that they are also being right. Between friends, there are some different kinds of friendship. Teachers told the children that they should be friends with everyone, but there are some boundaries. Friendship is based on trust, respect, and sharing. Therefore, children must respect each other and always take care of each other and to not hurt them (UNESCO, 2018). This value is given every day within the story or by a direct example from the teachers.
Teachers introduce the child about their environment, about their family, their friends, neighbors, and their teachers. Everyone has their role and needs. Between the family, they can take care of each other, to tell about their needs are necessary. However, there are different roles between a man and a woman. The tasks that a man and a woman should do and should not do are different, their responsibilities differ within the family (UNESCO, 2018)

Parents who were grouped in a forum with the school collaborated on sex education for children in Budi Mulia Dua Sedayu Kindergarten. This collaboration includes synchronizing sex education that is done in schools with sex education at home. Additionally, teachers and parents hold meetings and discuss together about sex education for early childhood. Discussions were conducted in the form of sharing about the reproductive organs of children, problems in the growth and development of children related to sex education, and alternative solutions to problems. In their daily lives, parents also have private discussions with the class teachers and expresses ideas and complaints about children sex education. Schools also provide psychological services if parents want further discussion.

Some parents used this service to discuss their child's problem, and they ask for the solution. But some parents do not want discuss it with the professionals. It can be because they are afraid to face the reality that the child had a problem, or because they felt shy to discuss a "taboo" subject with the professional. In this case, the parents' forum can provide the support and help needed for the parents who felt that way. The forum is a place where the parents can discuss their problems and they can find the way to solve it together. Parents discussing their children's problems are not taboo. It is a good way to know more about the growth and development of the children so the parents and teacher can do their job.

\section{CONCLUSION}

In terms of the implementation of sex education as a preventive action to the sexual abuse, Budi Mulia Dua Kindergarten and the parents have shown its seriousness in the act. It is proven by the school and parents' act to implement sex education with their cooperation in some programs like active dialogue, parenting program, and continuous treatment about sex education in both at school and at home. Parent and school's awareness of the recent sexual abuse issue is the reason in starting sex education program in school and home.

Parents and school did their best to teach sex education as early as possible. It can help the children to know more about their body, their sexual organ, and how to guard them. Sex education is not a taboo topic anymore. Sex education is something that everyone needs to know, especially children. The lack of awareness about sex education can lead to something bad, like sexual abuse. The teachers and parents are working together to create a good and friendly atmosphere for the children to support their best growth and development. The implementations also include some values of life, like how to treat each other, how everyone is 
different and that we should give some respect to it. There are some boundaries in a relationship and we should not cross it.

However, the parents and school are still not aware of some details like the toilet that is not divided by gender and some parents that still change their child's clothes in the public space. To be able to maximize sex education as a preventive action to sexual abuse, schools and parents need to be more aware of the details of what they should and shouldn't do in their daily lives.

\section{REFERENCES}

Alldred, P., \& David, M. E. (2007). Get real about sex: The politics and practice of sex education. England: Open University Press.

Carson, D. K., Foster, J. M., \& Tripathi, N. (2013). Child sexual abuse in India: Current issues and research. Psychological Studies, 58(3), 318-325

Gracia, C.K. (2015). Sexual health education in quebec schools: A critique and call for change. The Canadian Journal of Human Sexuality, 24(3), 197-204.

Kendall, N. (2013). The sex education debate. Chicago: University of Chicago Press.

Keyzers, A., Weiler, L., Haddock, S., \& Dotty, J. (2019). Family problem-solving and attachment quality: Associations with adolescent risk-taking behavior. Journal of Youth Development, 14(1), 70-92.

Marcovitz, H. (2013). How should sex education be taught in school. United States: Reference Point Press.

Matius, A. (July 24 $\left.{ }^{\text {th }} 2019\right)$. LPSK: Kasus kekerasan seksual pada anak meningkat tiap tahun. News Detik.com. Retrieved from https://news.detik.com/berita/d-4637744/lpsk-kasuskekerasan-seksual-pada-anak-meningkat-tiap-tahun.htm

Miles, M. B., Huberman, M. A., \& Saldana, J. (2014). Qualitative data analysis: A methods sourcebook. Edition 3. New York: SAGE Publication.

Reiss, M. J. (2016). Alternatives to school sex education. In The palgrave international handbook of alternative education (pp. 401-414). Palgrave Macmillan, London.

Sauntson, H., \& Sundaram, V. (2016). Global perspective and key debates in sex and relationships education: Addresing issues of gender, sexuality, plurality and power. New York: Palgrave Macmillan.

Sickkids staff. (June $6^{\text {th }}$ 2019). Sexuality: What children should learn and when. Retrieved from
https://www.aboutkidshealth.ca/Article?contentid=716 \&language $=$ English.htm

United Nations Educational, Scientific and Cultural Organization (UNESCO). (2018). International technical guidance on sexuality education: An evidence-informed approach. Paris: United Nations Educational, Scientific and Cultural Organization

United Nations Entity for Gender Equality and the Empowerment of Women (UN Woman). (2016). Global guidance on addressing school-related genderbased violence. Paris: United Nations Educational, Scientific and Cultural Organization (UNESCO) Publishing. 